\title{
PROPOSAL FOR THE SIZE OF THE FLEET TO PROVIDE WINTER ROAD MAINTENANCE
}

The article describes an optimisation model which was used to create the operation plan of winter road maintenance [6]. The model takes into consideration a number of factors of road description, such as road network topology, road categories and level of services. They result in suggesting the necessary number of vehicles the centres of winter road maintenance should have to be able to keep, the servicing time limit given by the operation plan in case of a calamity. The model also proposes what the most optimal vehicle routing would be timewise.

Key words: winter road maintenance, road gritting, vehicle routing problem, fleet sizing

\section{Introduction}

Performing winter road maintenance (WRM) is an important activity, necessary to keep the traffic on our roads in winter period safe and smooth. The appropriate authorities at all levels supposed to make sure roads are passable are the nation-wide authorities that administer the roads of the categories II and III, and the municipal authorities that are in charge of the roads and walkways in municipalities. Yearly, they all spend not a little money on the job. The finance they have to spend is not unlimited, of course, and the companies carrying out WRM often face the problem of having winter road maintenance machinery that is not functioning properly. This sometimes means the companies are not able to react to calamities sufficiently enough, which might result in dangerous traffic situations.

When WRM is well planned and organized, it is possible to achieve remarkable cost and energy savings, and at the same time to keep or even improve the operation level and quality of WRM.

\section{Problem formulation}

Let us have a road network consisting of individual road segments. The road network is divided into several regions. In the network there are fixed maintenance centres. Each of them has a given number of available winter maintenance vehicles (gritting vehicles, ploughs), as well as a given number of sufficiently dimensioned gritting material depots.

The WRM operation plan may be formally defined as follows: after a calamity emergency has been announced, the road network needs to become passable within a given time limit. The road categories determine the maintenance priority. Vehicle routings need to be planned and synchronized, so that the given time limit can be kept. The individual routings are represented by a sequenced list of road segments. The starting and finishing points of the list are identical - the maintenance centre. The routings do not need to be planned to be mutually excluding, which means some of the road segments can be part of several routings. Thus the routings of individual vehicles consist of two types of road segments: those the vehicle does WRM on, and those the vehicle just uses for transit.

The goal of the solution is to propose the minimal number of WRM vehicles necessary to keep the operation plan time limit. The proposal does not deal with changing the locations of the winter maintenance centres and gritting material depots, or with changing the road segments allocation to the individual regions.

\section{Proposed solution}

We are going to describe the road network of one region as a connected oriented graph $G=(V, E)$, where $G=\left\{v_{1}, v_{2}, \ldots, v_{n}\right\}$ is a vertex set and $E=\left\{\left(v_{i}, v_{j}\right): v_{i}, v_{j} \in V, i \neq j\right\}$ is an edge set. With every edge $\left(v_{i}, v_{j}\right)$ is associated a non-zero length $c_{i, j}$. Let $s c_{i, j}$ be the length of the shortest path connecting the vertex $v_{i}$ with the vertex $v_{i}$ in the graph $G$. Let $D \subset V$ be a set of the centres, each of them with a given number of vehicles.

The analysis of the problem has determined the type of the task to be solved: it is a modification of $C P P$ (Chinese postman problem). The modification is a result of the gritting vehicles capacity limitation, which leads to CCPP (Capacitated Chinese postman problem,

\footnotetext{
* Miroslav Gabor

Department of Software Technologies, Faculty of Management Science and Informatics, University of Zilina, Slovakia,

E-mail: miroslav.gabor@fri.uniza.sk
} 
as well as of the fact that not all of the edges require to be attended, which leads to RPP (Rural postman problem) [2].

The modifications named above make the task NP-difficult That is why it was suggested to use a heuristic approach to solve the task. The approach is based on the primary Clark-Wright heuristic method [1] modified to attend the edges in the oriented graph The method is further modified in dependence on the number of additional and limiting conditions [3].

The routings of individual gritting vehicles are calculated independently for each of the regions. We might describe the solution method in a simplified way as follows:

1. Selecting a random not gritted edge $\left(v_{i}, v_{j}\right)$ with the highest priority; we will call it the primary edge.

2. Allocating the primary edge $\left(v_{i}, v_{j}\right)$ to the nearest centre $v_{d} \in D$ with a gritting vehicle available.

3. Transferring the gritting vehicle from the centre $v_{d} \in D$ to the primary edge $\left(v_{i}, v_{j}\right)$ using the shortest path.

4. Gritting the primary edge and transferring to the centre, using the shortest path. The primary routing $\left\{v_{d}, \ldots, v_{i}, v_{j}, \ldots, v_{d}\right\}$ has originated.

5. Selecting a not gritted edge $\left(v_{k}, v_{i}\right)$ with the highest priority, the one closest to the primary edge.

6. Gritting the edge $\left(v_{k}, v_{i}\right)$ and inserting it into the routing $\left[v_{d}\right.$, $\left.\ldots, v_{i}, v_{j}, \ldots, v_{k}, v_{i}, \ldots, v_{d}\right]$.

7. If the routing takes less time than the time limit is, returning to the point 5 . Otherwise as follows:

8. Closing the routing.

9. If there is a not gritted edge remaining, returning to the point 1. Otherwise as follows:

10. Saving the solution and returning to the point 1 . Repeating the steps n-times.

11. Selecting the best solution which is the one than requires the lowest number of vehicles within the region, and the sum of the routing times of all vehicles is minimal.

12. The end of calculation within one region.

\section{Processing the documentation and creating the input data}

An important, and often also a much time consuming part of solving the task was to prepare the input data of good quality for the calculations [3]. We used the road network of Zilina self-governing region divided into five regions as the source of the input data for the solution. When transforming the road network into the graph, we identified the road segments from the map documentation as the graph edges, and they were allocated with the starting and ending nodes. The total number of the road segments is 727 , each of them is a two-way, which means the number of the edges in the graphs equals 1454 . Table 4.1 shows the number of edges for the individual regions.

Number of edges in the individual regions

Table 4.1

\begin{tabular}{|c|c|c|c|}
\hline Region & $\begin{array}{c}\text { Number of } \\
\text { edges }\end{array}$ & $\begin{array}{c}\text { Number of } \\
\text { centres }\end{array}$ & $\begin{array}{c}\text { Number of vehi- } \\
\text { cles }\end{array}$ \\
\hline Horne Povazie & 326 & 5 & 21 \\
\hline Liptov & 344 & 4 & 21 \\
\hline Turiec & 310 & 2 & 15 \\
\hline Orava & 270 & 3 & 25 \\
\hline Kysuce & 204 & 4 & 14 \\
\hline
\end{tabular}

Except the length there are more data defined for each of the edges:

- Routing - it is supposed to differentiate the roads of various width arrangements and ways of maintenance. It distinguishes two and more lane two-way roads with only one lane to be gritted in each direction, one-way roads with one lane to be gritted, four and more lane two-way roads where two vehicles move simultaneously in each of the directions during the maintenance, two and more lane one-way roads where two vehicles move simultaneously in one direction.

- Priority - a numerical entry which distinguishes the importance of the individual road segments transportation-wise; it depends on the category which the road the segment is a part of falls into.

- Demandingness - it takes into consideration the consumption of gritting material according to the type and complexity of a road segment. From the viewpoint of their demandingness segments are divided into critical (very dangerous), to be gritted with the dosage of $300 \mathrm{~g} / \mathrm{m}^{2}$ of mixed gritting material, dangerous with the dosage of $150 \mathrm{~g} / \mathrm{m}^{2}$, others with the dosage of $80 \mathrm{~g} / \mathrm{m}^{2}$, and not maintained segments.

Entries characterizing the edges

Table 4.2

\begin{tabular}{|c|c|c|c|c|c|c|c|c|c|}
\hline $\begin{array}{c}\text { Road } \\
\text { number }\end{array}$ & $\begin{array}{c}\text { Start. } \\
\text { node }\end{array}$ & $\begin{array}{c}\text { End. } \\
\text { node }\end{array}$ & Length & Routing & Priority & $\begin{array}{c}\text { Dem. } \\
\text { ness }\end{array}$ & $\begin{array}{c}\text { Gritting } \\
\text { speed }\end{array}$ & $\begin{array}{c}\text { Transit } \\
\text { speed }\end{array}$ & Name of the edge \\
\hline II / 520 & $4-10$ & $4-31$ & 7000 & 1 & 2 & 3 & 40 & 50 & KRASNO NAD K - KLUBINA \\
\hline II / 520 & $4-31$ & $4-32$ & 3800 & 1 & 2 & 3 & 40 & 50 & KLUBINA - RADOSTKA, connection \\
\hline II / 520 & $4-32$ & $4-33$ & 5130 & 1 & 2 & 3 & 40 & 50 & RADOSTKA, connection - NOV BYSTRICA \\
\hline II / 520 & $4-77$ & $5-118$ & 6500 & 1 & 3 & 5 & 25 & 25 & water reservoir BYSTRICA - ORAV LESNA, west \\
\hline III / 520003 & $4-32$ & $4-53$ & 2738 & 1 & 1 & 0 & 40 & 50 & RADOSTKA, connection - ST BYSTRICA \\
\hline III / 520001 & $4-32$ & $4-87$ & 3600 & 1 & 1 & 0 & 40 & 50 & RADOSTKA, connection - RADOSTKA 1 \\
\hline III / 520001 & $4-87$ & $1-130$ & 396 & 1 & 2 & 1 & 30 & 30 & RADOSTKA 1 - RADOSTKA \\
\hline
\end{tabular}


- Gritting speed of the vehicle - it takes into consideration how much the demandingness of a segment enables the vehicle to move. For critical segments, the speed was to $25 \mathrm{kms} / \mathrm{hr}$, for dangerous segments it is $30 \mathrm{kms} / \mathrm{hr}$, and for other segments it is $40 \mathrm{kms} / \mathrm{hr}$

- Transit speed of the vehicle - it takes into consideration how much the demandingness of a segment enables the vehicle to move. The speed values for critical and dangerous segments are identical with the gritting speeds, the transit speed for flat segments is set to $50 \mathrm{kms} / \mathrm{hr}$.

- Number of the road - it helps identify a given segment.

- Name - identification entry (text description of an edge) which makes it possible to identify the exact position of a segment on a road map.

Vertex of the graph represent the vehicle centres, and they are allocated with the existing numbers of vehicles. Table 4.3 is an example for the region of Kysuce.

Numbers of vehicles in the region of Kysuce

Table 4.3

\begin{tabular}{|c|c|}
\hline Centre & Number of gritting vehicles \\
\hline Kysucke Nove Mesto & 5 \\
\hline Makov & 5 \\
\hline Stara Bystrica & 2 \\
\hline Podvysoká & 2 \\
\hline
\end{tabular}

Gritting vehicle routing

\begin{tabular}{|c|c|c|c|c|c|}
\hline \multicolumn{6}{|c|}{ Centre: Stara Bystrica, routing 1. Time of routing: 118.69 minutes, length of routing: $68.01 \mathrm{kms}$} \\
\hline $\begin{array}{c}\text { Seq. } \\
\text { number }\end{array}$ & $\begin{array}{c}\text { Road } \\
\text { number }\end{array}$ & $\begin{array}{l}\text { Starting } \\
\text { vertex }\end{array}$ & $\begin{array}{l}\text { Ending } \\
\text { vertex }\end{array}$ & Action & Name of edge \\
\hline 1. & III / 520003 & $4-53$ & $4-32$ & gritting & ST BYSTRICA - RADOSTKA, connection \\
\hline 2. & II / 520 & $4-32$ & $4-33$ & gritting & RADOSTKA, connection - NOV BYSTRICA \\
\hline 3. & II / 520 & $4-33$ & $4-34$ & gritting & NOV BYSTRICA - VYCHYLOVKA, connection \\
\hline 4. & II / 520 & $4-34$ & $4-35$ & gritting & VYCHYLOVKA, connection - NOV BYSTRICA, east \\
\hline 5. & II / 520 & $4-35$ & $4-77$ & gritting & NOV BYSTRICA, east - water reservoir BYSTRICA \\
\hline 6. & II / 520 & $4-77$ & $5-118$ & gritting & nadrz BYSTRICA - ORAV LESNÁ, west \\
\hline 7. & II / 520 & $5-118$ & $4-77$ & gritting & ORAV LESNA, west - water reservoir BYSTRICA \\
\hline 8. & II / 520 & $4-77$ & $4-35$ & gritting & water reservoir BYSTRICA - NOV BYSTRICA, east \\
\hline 9. & II / 520 & $4-35$ & $4-34$ & gritting & NOV BYSTRICA, east - VYCHYLOVKA, connection \\
\hline 10. & II / 520 & $4-34$ & $4-33$ & gritting & VYCHYLOVKA, connection - NOV BYSTRICA \\
\hline 11. & II / 520 & $4-33$ & $4-32$ & gritting & NOV BYSTRICA - RADOSTKA, connection \\
\hline 12. & III / 520003 & $4-32$ & $4-53$ & gritting & RADOSTKA, connection - ST BYSTRICA \\
\hline 13. & & & & loading & \\
\hline 14. & III / 520003 & $4-53$ & $4-32$ & transit & ST BYSTRICA - RADOSTKA, connection \\
\hline 15. & II / 520 & $4-32$ & $4-31$ & gritting & RADOSTKA, connection - KLUBINA \\
\hline 16. & II / 520 & $4-31$ & $4-10$ & gritting & KLUBINA - KRASNO NAD K \\
\hline 17. & II / 520 & $4-10$ & $4-31$ & gritting & KRASNO NAD K - KLUBINA \\
\hline 18. & II / 520 & $4-31$ & $4-32$ & gritting & KLUBINA - RADOSTKA, connection \\
\hline 19. & III / 520003 & $4-32$ & $4-53$ & transit & RADOSTKA, connection - ST BYSTRICA \\
\hline
\end{tabular}

\section{Assessing the current situation and proposing the required number of vehicles}

We did calculations for the input entries above, and processed several of their outputs into tables. They provide an overview of numbers of gritting vehicles in the regions (Table 5.1) and in the

Proposed number of vehicles for the individual regions Table 5.1

\begin{tabular}{|c|c|c|c|c|}
\hline Region & Current situation & Proposal & Surplus & Shortage \\
\hline Horne Povazie & 21 & 21 & - & - \\
\hline Liptov & 21 & 26 & - & 5 \\
\hline Turiec & 15 & 15 & - & - \\
\hline Orava & 25 & 23 & 2 & - \\
\hline Kysuce & 14 & 16 & - & 2 \\
\hline
\end{tabular}

Proposed number of vehicles for the centres

Table 5.2 of the region of Kysuce

\begin{tabular}{|l|c|c|c|c|}
\hline Region & $\begin{array}{c}\text { Current sit- } \\
\text { uation }\end{array}$ & Proposal & Surplus & Shortage \\
\hline Kysucke N. Mesto & 5 & 8 & - & 3 \\
\hline Makov & 5 & 6 & - & 1 \\
\hline Stara Bystrica & 2 & 2 & - & - \\
\hline Podvysoka & 2 & 0 & 2 & - \\
\hline SPOLU & 14 & 16 & 2 & 4 \\
\hline
\end{tabular}

Table 5.3 
individual centres (Table 5.2) that are necessary to keep the given 120-minute time period for WRM.

Apart from proposing the number of vehicles, we designed a routing for each vehicle, defined by the sequence of the edges and with the information whether the given edge is supposed to be gritted or just transited without gritting. There is an example in Table 5.3 with a routing proposed for one of the vehicles of the centre Stara Bystrica in the region of Kysuce.

\section{Conclusion}

The proposed solution suggests such numbers of vehicles that are able to carry out WRM in the required quality. We suggested routings for WRM vehicles for the time limits set for carrying out WRM.

To a great extent, the results are influenced by the values of the input data - gritting material consumption, WRM vehicles speed when gritting the road segments and when transiting the road segments that do not require to be gritted. Last but not least the results are also influenced by the division of the road segments into critical (very dangerous), dangerous and others. Specifying them will increase the reliability of the calculations.

Also the number of simplifications of the suggested solution has an impact on the accuracy of the results. Moreover, it is possible to improve the proposed heuristic, too, and more research is being done into the possibility to combine proposed routings within one centre, re-calculate them and look for potential improvements.

\section{Acknowledgement:}

This contribution is the result of the project implementation: Centre of excellence for systems and services of intelligent transport, ITMS 26220120028 supported by the Research \& Development Operational Programme funded by the ERDF.

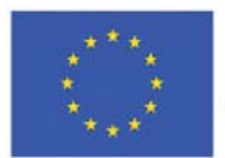

Európska únia

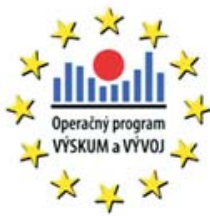

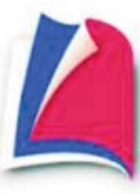

Agentúra

Ministerstva školstva, vedy, výskumu a športu SR pre štrukturálne fondy EÚ

"Podporujeme vyskumne aktivity na Slovensku/Projekt je spolufinancovany zo zdrojov EU."

\section{References}

[1] JANACEK, J.: Optimization in Transport Networks (in Czech), EDIS-ZU, Zilinska univerzita : Zilina, 2003, p. 248.

[2] PALUCH, S., PESKO, S.: Quantitative Methods in Logistics, Monograph, EDIS-ZU, Zilinska univerzita : Zilina, 2007, 185 p., ISBN 80-8070-636-0

[3] VALUCH, M., GABOR, M., TROJANOVA, M., PAZUR, P.: Winter Road Maintenance Operations for $2^{\text {nd }}$ and $3^{\text {rd }}$ Class Roads in Self-governing Region Agency (in Slovak), $11^{\text {th }}$ International Conference Q-2009, 2009, Zilina : Krupa print, pp. 220-225, ISBN 978 80-970139-0-5.

[4] PERRIER N, LANGEVIN A, CAMPBELl J. F.: A Survey of Models and Algorithms for Winter Road Maintenance. Part III: Vehicle Routing and Depot Location for Spreading, In: Computers \& Operations Research, 2004.

[5] PERRIER N, LANGEVIN A, CAMPBELL J. F.: A Survey of Models and Algorithms for Winter Road Maintenance. Part IV: Vehicle Routing and Fleet Sizing for Plowing and Snow Disposal, In: Computers \& Operations Research, 2004.

[6] Winter Road Maintenance Operational Plan of Zilina Self-governing Region (in Slovak), winter season 2009/2010, Zilina self-governing region Road Administration, 2009. 